\title{
Evaluating Energy Performance Certificate Data with Data Science
}

\author{
Maria Anastasiadou \\ Information Management School \\ NOVA Information Management School \\ Lisbon, Portugal \\ 0000-0003-2770-7025 \\ Vítor Santos \\ Information Management School \\ NOVA Information Management School \\ Lisbon, Portugal \\ 0000-0002-4223-7079 \\ Miguel Sales Dias \\ ISCTE-IUL \\ Instituto Universitário de Lisboa \\ Lisbon, Portugal \\ 0000-0002-1445-2695
}

\section{This is the accepted version of the conference paper published by IEEE}

\section{publisher}

Anastasiadou, M., Santos, V., \& Dias, M. S. (2021). Evaluating Energy Performance Certificate Data with Data Science. In 2021 International Conference on Electrical, Computer and Energy Technologies (ICECET) (pp. 1-5). (ICECET 2021, 9-10 December, Cape Town, South Africa). IEEE. https://doi.org/10.1109/ICECET52533.2021.9698806

(C) 2021 IEEE. Personal use of this material is permitted. Permission from IEEE must be obtained for all other uses, in any current or future media, including reprinting/republishing this material for advertising or promotional purposes, creating new collective works, for resale or redistribution to servers or lists, or reuse of any copyrighted component of this work in other works. 


\section{Evaluating Energy Performance Certificate Data with Data Science}

\author{
Maria Anastasiadou \\ Information Management School \\ NOVA Information Management \\ School \\ Lisbon, Portugal \\ 0000-0003-2770-7025
}

\author{
Vítor Santos \\ Information Management School \\ NOVA Information Management \\ School \\ Lisbon, Portugal \\ 0000-0002-4223-7079
}

\author{
Miguel Sales Dias \\ ISCTE-IUL \\ Instituto Universitário de Lisboa \\ Lisbon, Portugal \\ 0000-0002-1445-2695
}

\begin{abstract}
The related problems of improving existing buildings' energy performance, reducing energy consumption, and improving indoor comfort and their many consequences are well known. Considering increasing urbanization and climate change, governments define strategies to enhance and measure buildings' energy performance and energy efficiency. This work aims to contribute to the improvement of buildings' characteristics by conducting a thorough systematic literature review and adopting a data science approach to these problems, presenting initial results with an open-access energy performance certificate dataset from the Lombardy Region, in Italy. We provide a pre-processing method to the data, applicable for future research, aiming to address challenges such as automatic classification of existing buildings' energy performance certification, and predicting energy-efficient retrofit measures, using machine learning techniques. The analysis of this dataset is challenging because of the high variability and dimensionality of this dataset. For this purpose, a robust iterative process was developed. First, the data dimensionality was reduced with Pearson Correlation to find the best set of variables against the non-renewable global energy performance index (EPgl, nren). Then, the outliers were handled by utilizing Box Plot and Isolation Forest algorithms. The main contribution is to inform private and public building sectors on dealing with high dimensional data to achieve enhanced energy performance and predict energyefficient retrofit measures to improve their energy performance.
\end{abstract}

Keywords- Energy performance of buildings, energy performance certification, machine learning, prediction of retrofitting measures

\section{INTRODUCTION}

Data science and machine learning (ML) techniques are used to analyze and improve buildings' energy efficiency. Hence, to minimize energy consumption, design energy-efficient buildings, define strategies for mitigating impacts on the climate and environment, and predict and propose useful, cost-effective retrofit measures to increase buildings' energy efficiency to provide a comfortable indoor living environment [1,2].

The analysis and classification of energy performance classification datasets are challenging because of their high variability and dimensionality [3]. Existing ML techniques can exploit historical data knowledge and support decision-makers in the energy domain [1].

In this context, this research aims to improve buildings' energy performance and energy efficiency by identifying the latest and most appropriate ML and statistical techniques by analyzing and pre-processing an open-access energy performance certificate dataset from the Lombardy Region, Italy. We aim to create the basis of future research by performing automatic classification of existing buildings' energy performance certification. We started to conduct a thorough systematic literature review (SLR) and then completed the analysis of the dataset by reducing the data dimensionality with Pearson Correlation to find the best set of variables against the non-renewable global energy performance index (EPgl, nren). Then the outliers were handled utilizing Box Plot and Isolation Forest algorithm.

By analyzing this type of data and preparing to build the pillars for future research, we aim to inform private and public building sectors on achieving enhanced energy performance and predicting energy-efficient retrofit measures in a more accurate, practical, and efficient way, thus contributing to the 7th Sustainable Development Goal (SDG), "Ensure access to affordable, reliable, sustainable and modern energy for all" of the United Nations [4].

This paper is structured as follows, Section 2 introduces this study's methodology and section 3 describes the adopted systematic literature review. Section 4 presents the data preprocess and analysis. Finally, section 5 covers the conclusions and future work.

\section{Methodology}

Cross-Industry Standard Process, a well-established Data Mining methodology, has inspired the methodology of this work [18]. The main phases of this work are thus:

Phase 1: Conduct an SLR to select the best basis for reporting systematic reviews to identify and analyze the most relevant approaches to energy performance certificate (EPC) classification to improve the energy performance of buildings machine reading. 
Phase 2: Pre-processing and analyses of the open-access energy performance certificate dataset from the Lombardy Region, Italy [5], with the objective to prepare a good, clean and normalized dataset to base the research and the follow-up analysis tasks.

\section{SySTEMATIC LITERATURE REVIEW}

The literature search was performed in April 2021 using the following data repositories: Science Direct, Web of Science and Scopus. All papers published between 1st January 2016 and27th of April 2021 were included. The final SLR papers for quantitative and qualitative analysis was structured using the Mendeley reference manager and open-source tool [6]. This allowed us to extract metadata and remove duplicates. This analysis yielded 35 papers. Table 1 shows the results of this process, with the top 10 most cited papers, their dimensions, methods, and citation number.

\begin{tabular}{|c|c|c|c|}
\hline \multirow{2}{*}{ Ref } & \multicolumn{3}{|c|}{ Top 10 Papers } \\
\hline & Dimension & Methods & N. of Citations \\
\hline [7] & $\begin{array}{l}\text { Thermo-physical } \\
\text { characteristics, } \\
\text { Building envelop, } \\
\text { HVAC systems. } \\
\text { Weather, Energy } \\
\text { use }\end{array}$ & $\begin{array}{l}\text { Simulation, Latin } \\
\text { hypercube } \\
\text { sampling, Pareto- } \\
\text { sensitive analysis, } \\
\text { Genetic Algorithm }\end{array}$ & 84 \\
\hline [8] & $\begin{array}{l}\text { Climatic location, } \\
\text { Geometry, } \\
\text { Construction } \\
\text { elements, Building } \\
\text { properties, } \\
\text { Internal } \\
\text { temperature } \\
\text { measures }\end{array}$ & $\begin{array}{l}\text { Genetic Algorithm } \\
\text { NSGA-II, } \\
\text { Simulation, } \\
\text { Parametric } \\
\text { analysis, } \\
\text { Sensitivity } \\
\text { analysis, } \\
\text { Uncertainty } \\
\text { analysis: } \\
\text { CV(RMSE) fi, } \\
\end{array}$ & 44 \\
\hline [9] & $\begin{array}{l}\text { Building } \\
\text { envelope, } \\
\text { Building } \\
\text { operation, HVAC } \\
\text { systems, Financial } \\
\text { attributes } \\
\end{array}$ & $\begin{array}{l}\text { Genetic } \\
\text { algorithms, } \\
\text { Transient energy } \\
\text { simulations }\end{array}$ & 44 \\
\hline [10] & $\begin{array}{l}\text { Building } \\
\text { Envelope, HVAC } \\
\text { systems, Internal } \\
\text { heat gains, } \\
\text { Weather, Cost of } \\
\text { different } \\
\text { renovation } \\
\text { measures }\end{array}$ & $\begin{array}{l}\text { Simulation-based } \\
\text { Optimization } \\
\text { methods, Pareto- } \\
\text { Archive NSGA-II } \\
\text { Genetic algorithm }\end{array}$ & 39 \\
\hline [11] & $\begin{array}{l}\text { Thermophysical } \\
\text { parameters, } \\
\text { HVAC plants, } \\
\text { Typology, } \\
\text { Buildings } \\
\text { characteristics, } \\
\text { Climate, } \\
\text { Geometry, Energy } \\
\text { consumption }\end{array}$ & $\begin{array}{l}\text { Artificial neural } \\
\text { networks (ANN) }\end{array}$ & 37 \\
\hline [12] & $\begin{array}{l}\text { Climatic location, } \\
\text { Building } \\
\text { materials, } \\
\text { Financial } \\
\text { attributes }\end{array}$ & $\begin{array}{l}\text { Life-Cycle Cost } \\
\text { method, Monte } \\
\text { Carlo simulation, } \\
\text { Discount rate }\end{array}$ & 35 \\
\hline [13] & $\begin{array}{l}\text { Design variables, } \\
\text { Climate (Thermal } \\
\text { zone), Cooling and } \\
\text { heating }\end{array}$ & $\begin{array}{l}\text { Pareto front, } \\
\text { Simulation, Non- } \\
\text { dominated Sorting } \\
\text { Genetic }\end{array}$ & 30 \\
\hline
\end{tabular}

\begin{tabular}{|c|c|c|c|}
\hline \multirow{2}{*}{ Ref } & \multicolumn{3}{|c|}{ Top 10 Papers } \\
\hline & Dimension & Methods & N. of Citations \\
\hline & & $\begin{array}{l}\text { Algorithm-II } \\
\text { (NSGA-II) }\end{array}$ & \\
\hline [14] & $\begin{array}{l}\text { Geometry, } \\
\text { Weather, } \\
\text { Construction } \\
\text { materials }\end{array}$ & $\begin{array}{l}\text { Energy } \\
\text { Simulation, } \\
\text { Residual network } \\
\text { model }\end{array}$ & 27 \\
\hline [15] & $\begin{array}{l}\text { Climate, Building } \\
\text { location, Energy } \\
\text { sources (gas and } \\
\text { electricity), } \\
\text { Building } \\
\text { characteristics, } \\
\text { Installation } \\
\text { systems }\end{array}$ & $\begin{array}{l}\text { Simulations, } \\
\text { Active Archive } \\
\text { Non-Dominated } \\
\text { Sorting Genetic } \\
\text { Algorithm } \\
\text { (aNSGA-II type), } \\
\text { Pareto frontier }\end{array}$ & 22 \\
\hline [16] & $\begin{array}{l}\text { Weather, Building } \\
\text { Envelope, HVAC } \\
\text { systems, Energy } \\
\text { use }\end{array}$ & $\begin{array}{l}\text { Latin-hypercube } \\
\text { sampling, Joint } \\
\text { mutual } \\
\text { information } \\
\text { maximization, } \\
\text { Energy } \\
\text { conservation } \\
\text { measure }\end{array}$ & 21 \\
\hline
\end{tabular}

\section{TABLE I. TOP 10 MOST CITED PAPERS}

The 10 top most cited papers used a combination of simulation techniques, namely, Pareto front, genetic algorithm NSGA-II, and artificial neural networks (ANN) (Table 5). Also, they used for analysis the following variables/dimensions extracted from data: climate and weather, building thermophysical characteristics, building envelope, building geometry, HVAC systems, energy consumption and buildings typology. As case studies, most of them used residential buildings (6), offices (1), universities (2), schools (1) and hospitals (1), [7-16]. By summarizing the analyzed literature, most of the studies used simulation techniques for classification. Few studies used data science and ML approaches for energy performance certificate classification, such as clustering analysis [17]. This last technique is considered one of the most applied techniques in classifying energy data in different buildings, finding patterns and group data $[3,17]$. Most of the studies applied K-means clustering to characterize the cluster sets [18-20]. Box plot statistical analysis and dbscan were used by such literature to eliminate outliers and noise due to their ability to deal with complex and high-dimensional data. Correlation analysis showed as well that the best approach was to estimate the importance of each analyzed input dimension. All the above indicate a knowledge gap in using ML to perform classification, as most studies used simulation techniques, leaving opportunities for future research.

\section{PRE-PROCESSING \& DATA ANALYSIS}

\section{A. Data}

The dataset "CENED +2 - Certificazione ENergetica degli EDifici" was used and analyzed in this study. This dataset is open-access and contains energy performance certificate data related to buildings' energy performance class from the Lombardy Region, Italy [5]. Furthermore, the dataset has 948K of data size related to the energy performance and energy certification class between the years $2016-2021$. Only the data of public buildings were selected, 6465 rows, given that this study focuses on the public sector. The dataset was already 
normalized, with no duplicate or missing values; some had zero values but not in critical columns for this study, see table 2 .

Table 2 reports the core subset of available characteristics (with the corresponding notation and units) grouped into 4 groups for each energy certificate (climate, building characteristics, energy performance, and the efficiency of the subsystems for space heating). The dataset contained info on the system features, building envelope and primary energy demand for each hot water and heating space.

\begin{tabular}{|c|c|c|}
\hline \multicolumn{3}{|c|}{ A subset of values characterizing EPC's } \\
\hline $\begin{array}{c}\text { Category } \\
\text { Name }\end{array}$ & Attribute name [Units] & Notation \\
\hline Clime & Climate zone [-] & Zone_climate \\
\hline \multirow{6}{*}{$\begin{array}{l}\text { Buildings } \\
\text { characteristics }\end{array}$} & Year of construction $[-]$ & Y_construction \\
\hline & $\begin{array}{l}\text { Summer equivalent solar } \\
\text { area per unit of useful area }\end{array}$ & $\begin{array}{l}\text { A_SOL_EST_A_SUP } \\
\text { _UTILE }\end{array}$ \\
\hline & Floor Area [m2] & Floor_area \\
\hline & Heated volume [m3] & H_volume \\
\hline & Heat transfer surface $[\mathrm{m} 2]$ & H_surface \\
\hline & $\begin{array}{l}\text { Ratio of the dispersing area } \\
\text { to the gross volume of the } \\
\text { building [m-1] }\end{array}$ & Ratio_SV \\
\hline \multirow{2}{*}{$\begin{array}{l}\text { Efficiency of } \\
\text { the } \\
\text { subsystems } \\
\text { for space } \\
\text { heating }\end{array}$} & $\begin{array}{ll}\text { Emission } & \mathrm{CO} 2 \\
{[\mathrm{~kg} / \mathrm{m} 2 \text { anno }],} & \end{array}$ & Emission_CO2 \\
\hline & $\begin{array}{ll}\text { Energy } & \text { consumption } \\
\text { [kWh/anno]. } & \\
\end{array}$ & Energy_consum \\
\hline \multirow{10}{*}{$\begin{array}{l}\text { Energy } \\
\text { performance }\end{array}$} & Energy class label [-] & Energy_class \\
\hline & $\begin{array}{l}\text { Index non - renewable } \\
\text { global energy performance } \\
{[\mathrm{kWh} / \mathrm{m} 2 \text { anno] }}\end{array}$ & EP_GL_NREN \\
\hline & $\begin{array}{l}\text { Index renewable global } \\
\text { energy } \\
{[\mathrm{kWh} / \mathrm{m} 2 \mathrm{anno}]}\end{array}$ & EP_GL_REN \\
\hline & $\begin{array}{l}\text { Index thermal performance } \\
\text { useful for winter air } \\
\text { conditioning } \\
{[\mathrm{kWh} / \mathrm{m} 2 \mathrm{anno}]}\end{array}$ & EP_H_ND \\
\hline & $\begin{array}{l}\text { Index of primary energy } \\
\text { non - renewable refers to } \\
\text { winter air conditioning } \\
{[\mathrm{kWh} / \mathrm{m} 2 \mathrm{anno}]}\end{array}$ & CI_EPNREN \\
\hline & $\begin{array}{l}\text { Index of primary energy } \\
\text { renewable refers to winter } \\
\text { air conditioning } \\
{[\mathrm{kWh} / \mathrm{m} 2 \mathrm{anno}]}\end{array}$ & CI_EPREN \\
\hline & $\begin{array}{l}\text { Index of primary energy } \\
\text { non - renewable refers to } \\
\text { summer air conditioning } \\
{[\mathrm{kWh} / \mathrm{m} 2 \text { anno] }}\end{array}$ & CE_EPNREN \\
\hline & $\begin{array}{l}\text { Index of primary energy } \\
\text { renewable refers to summer } \\
\text { air conditioning } \\
{[\mathrm{kWh} / \mathrm{m} 2 \mathrm{anno}]}\end{array}$ & CE_EPREN \\
\hline & $\begin{array}{l}\text { Index of primary energy } \\
\text { non - renewable refers to } \\
\text { lighting }[\mathrm{kWh} / \mathrm{m} 2 \mathrm{anno}]\end{array}$ & ILL_EPNREN \\
\hline & $\begin{array}{l}\text { Index of primary energy } \\
\text { renewable refers to - } \\
\text { lighting }[\mathrm{kWh} / \mathrm{m} 2 \mathrm{anno}]\end{array}$ & ILL_EPREN \\
\hline
\end{tabular}

\begin{tabular}{|c|c|c|}
\hline \multicolumn{3}{|c|}{ A subset of values characterizing EPC's } \\
\hline Category & Attribute name [Units] & Notation \\
\hline & $\begin{array}{l}\text { Index of primary energy } \\
\text { non - renewable refers to } \\
\text { production of domestic hot } \\
\text { water [kWh/m2anno] }\end{array}$ & PA_EPNREN \\
\hline & $\begin{array}{l}\text { Index of primary energy } \\
\text { renewable refers to - } \\
\text { production of domestic hot } \\
\text { water }[\mathrm{kWh} / \mathrm{m} 2 \mathrm{anno}]\end{array}$ & PA_EPREN \\
\hline & $\begin{array}{l}\text { Index of primary energy } \\
\text { non - renewable refers to } \\
\text { production of ventilation } \\
{[\mathrm{kWh} / \mathrm{m} 2 \mathrm{anno}]}\end{array}$ & VM_EPNREN \\
\hline & $\begin{array}{l}\text { Index of primary energy } \\
\text { renewable refers to - } \\
\text { production of ventilation } \\
{[\mathrm{kWh} / \mathrm{m} 2 \mathrm{anno}]}\end{array}$ & VM_EPREN \\
\hline & $\begin{array}{l}\text { Index of primary energy } \\
\text { non - renewable refers to } \\
\text { production of transport of } \\
\text { people }[\mathrm{kWh} / \mathrm{m} 2 \mathrm{anno}]\end{array}$ & TPC_EPNREN \\
\hline & $\begin{array}{l}\text { Index of primary energy } \\
\text { renewable refers to - } \\
\text { production of transport of } \\
\text { people }[\mathrm{kWh} / \mathrm{m} 2 \mathrm{anno}]\end{array}$ & TPC_EPREN \\
\hline
\end{tabular}

TABLE II. A SUBSET OF VALUES CHARACTERIZING EPC'S

According to the "Decreto dei requisiti minimi e linee guida per la certificazione energetica" Ministerial Decree 26/06/2015 [21], the energy class is determined by calculating the global non-renewable global energy performance index (sum of all indexes) EPgl, nren [22,23]:

\section{$E P g l$, nren $=E P H$, nren $+E P C$, nren $+E P W$, nren + $E P V$, nren $+E P L$, nren $+E P T$, nren (1)}

This index considers the non-renewable primary energy requirement for summer and winter air conditioning (EPH, nren and EPC, nren), to produce hot water (EPW, nren), for ventilation (EPV, nren) and, in the case of the non-residential sector, for artificial lighting (EPL, nren) and the transport of people or objects (EPT, nren). It is determined as the sum of the individual energy services provided in the building and is expressed in $\mathrm{kWh} / \mathrm{m} 2 /$ year in relation to the reference area [22,23]. Figure 1 shows the EPgl, nren Range according to the "Decreto dei requisiti minimi e linee guida per la certificazione energetica" Ministerial Decree 26/06/2015 [21] and the energy performance certificates.

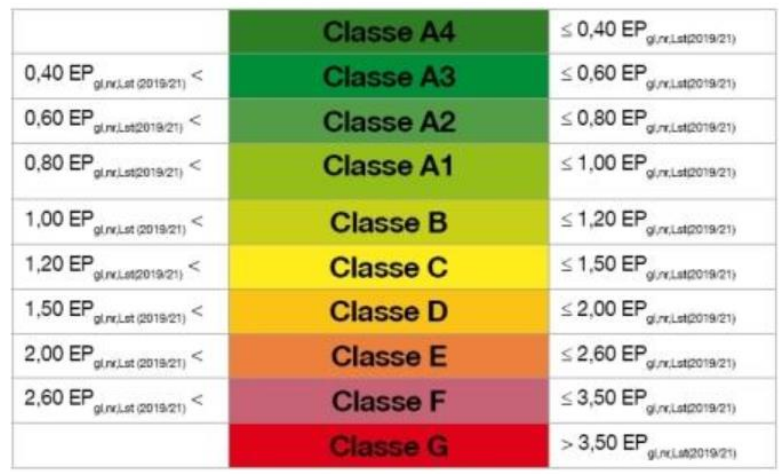

Fig. 1. EPgl, nren Range [20,21] 


\section{B. Correlation analysis}

In this context, the data dimensionality was reduced using Pearson Correlation [3,24](see figure 2) to find the best set of variables against the non-renewable global energy performance index (EPgl, nren, EP_GL_NREN), to decrease the space and time complexity of data mining algorithms. The correlation matrix was leveraged to evaluate the dependency between various variables at the same time. The greater the coefficient values are, the greater the correlation is for each pair of characteristics with the Pearson correlation higher than 0.60 $[3,24]$. The weights that are more correlated to EPgl, nren (EP_GL_NREN) were only considered. This step allowed to smooth and improve the noisy data, thus the next analytics steps' efficiency. The results showed that the most critical complaints were emission CO2 (Emission_CO2), thermal performance index useful for winter air conditioning (EP_H_ND) and the index of primary energy renewable refers to winter air conditioning (CI_EPNREN), where this research is focusing.

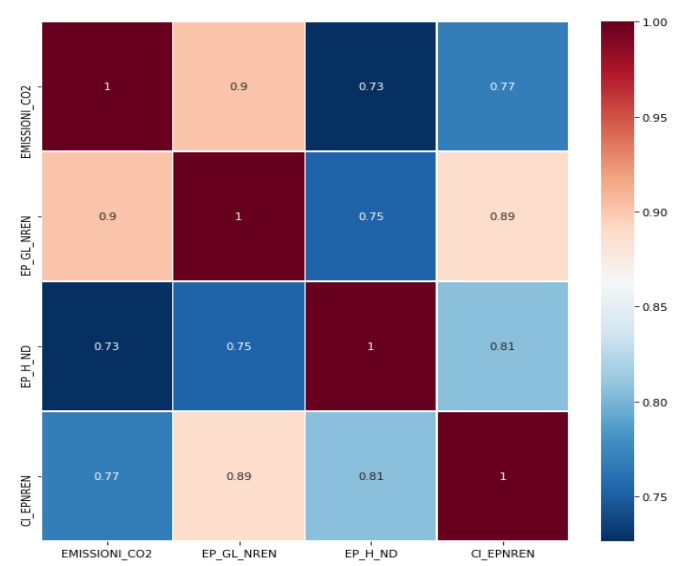

Fig. 2. Pearson Correlation Analysis

\section{Handle Outliers}

To handle outliers, two data science and ML techniques were used. At first, the Box Plot techniques were used, and then the Isolation Forest algorithms were applied to the Box Plot results. Isolation Forest algorithms is an unsupervised learning algorithm for anomaly and outlier's detection [25]. Many authors used Box Plot and Isolation Forest for outlier detection to detect anomalies instead of normal observations[26-30]. It can be scaled up to handle large, high-dimensional datasets and built on a set of binary (isolation) trees [26-30]. Figure 3 shows the box plot analysis of the EPgl, nren with Energy class.

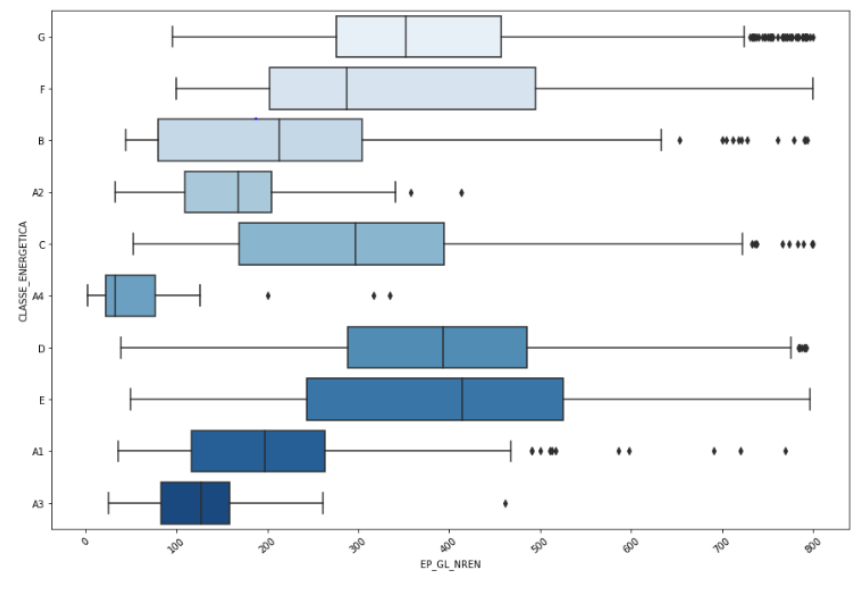

Fig. 3. Box Plot Analysis

Finally, after the outlier removal process, the dataset resulted in 5839 rows, $90 \%$ of the original data, given that we had to remove $10 \%$ of the data, 626 rows. The above steps allowed us to detect and remove noisy data, thus improving the next analytics steps.

\section{CONCLUSION}

The SLR summarized and generated a systematic view of ML and statistical approaches applied to improving buildings' energy performance, which can be used for future research. Most studies use, process, and analyze EPC datasets, adopting simulation techniques, providing opportunities for future research. As identified in the SLR, the Box plot and Isolation Forest algorithms are robust techniques to eliminate outliers and noise due to their ability to deal with complex and highdimensional data. Correlation analysis showed that the best approach was to estimate the importance of each analyzed input dimension. All the above steps allowed us to smooth and improve the noisy data. Efficacy of the following analytics steps, build the basis for future research, aiming to perform automatic classification of existing public buildings' energy performance certification using ML.

These research findings identified knowledge gaps and opened a methodological agenda that will help identify effective combinations of ML and statistical approaches, addressing the problems of automatic classification.

The future steps are to use this analysis as a base to perform automatic classification of existing public buildings' energy performance certification using the K-means as clustering technique and the Self-organizing Map algorithm to exploit and compare to discover the best performing algorithms to groups of energy performance classification with similar features.

\section{ACKNOWLEDGMENT}

We wish to thank Ricardo Pinto and Vitória Albuquerque for their assistance in reviewing the paper. The authors would also like to thank the editorial team and the reviewers who offered constructive and helpful remarks to enhance the quality of the paper.

\section{REFERENCES}


[1] M.U. Mehmood, D. Chun, Zeeshan, H. Han, G. Jeon, K. Chen, A review of the applications of artificial intelligence and big data to buildings for energy-efficiency and a comfortable indoor living environment, Energy Build. $202 \quad 109383$. https://doi.org/10.1016/j.enbuild.2019.109383.

[2] M. Molina-Solana, M. Ros, M.D. Ruiz, J. Gómez-Romero, M.J. MartinBautista, Data science for building energy management: A review, Renew. Sustain. Energy Rev. 70 (2017) 598-609. https://doi.org/10.1016/j.rser.2016.11.132.

[3] E. Di Corso, T. Cerquitelli, M.S. Piscitelli, A. Capozzoli, Exploring energy certificates of buildings through unsupervised data mining techniques, Proc. - 2017 IEEE Int. Conf. Internet Things. 2018-Janua (2018) 991-998. https://doi.org/10.1109/iThings-GreenCom-CPSComSmartData.2017.152.

[4] United Nations, Transforming our world: the 2030 Agenda for Sustainable Development, (2020). https://sdgs.un.org/2030agenda.

[5] Regione Lombardia, Database CENED+2 - Certificazione ENergetica degli EDifici, Reg. Lomb. https://www.dati.lombardia.it/Energia/Database-CENED-2Certificazione-ENergetica-degli-E/bbky-sde5.

[6] Mendeley, Mendeley, Elsevier. https://www.mendeley.com/?interaction_required=true.

(2019).

7] F. Ascione, N. Bianco, C. De Stasio, G.M. Mauro, G.P. Vanoli, Multistage and multi-objective optimization for energy retrofitting a developed hospital reference building: A new approach to assess cost-optimality, Appl. $\quad$ Energy. $\quad 174$ (2016) 37-68. https://doi.org/https://doi.org/10.1016/j.apenergy.2016.04.078.

[8] G. Ramos Ruiz, C. Fernández Bandera, T. Gómez-Acebo Temes, A. Sánchez-Ostiz Gutierrez, Genetic algorithm for building envelope calibration, Appl. Energy. 168 (2016) 691-705. https://doi.org/https://doi.org/10.1016/j.apenergy.2016.01.075.

[9] F. Ascione, N. Bianco, R.F. De Masi, G.M. Mauro, G.P. Vanoli, Energy retrofit of educational buildings: Transient energy simulations, model calibration and multi-objective optimization towards nearly zero-energy performance, ENERGY Build. 144 (2017) 303-319.

[10] T. Niemelä, R. Kosonen, J. Jokisalo, Cost-effectiveness of energy performance renovation measures in Finnish brick apartment buildings, $\begin{array}{llll}\text { Energy } & \text { Build. } & 137 & \text { (2017) }\end{array}$ https://doi.org/https://doi.org/10.1016/j.enbuild.2016.12.031.

[11] [M. Beccali, G. Ciulla, V. Lo Brano, A. Galatioto, M. Bonomolo, Artificial neural network decision support tool for assessment of the energy performance and the refurbishment actions for the non-residential building stock in Southern Italy, ENERGY. 137 (2017) 1201-1218. https://doi.org/10.1016/j.energy.2017.05.200.

[12] S. Copiello, L. Gabrielli, P. Bonifaci, Evaluation of energy retrofit in buildings under conditions of uncertainty: The prominence of the discount $\begin{array}{llll}\text { rate, } & \text { ENERGY. } & 137 & \text { (2017) }\end{array}$ https://doi.org/10.1016/j.energy.2017.06.159.

[13] F. Bre, V.D. Fachinotti, A computational multi-objective optimization method to improve energy efficiency and thermal comfort in dwellings, $\begin{array}{llll}\text { Energy } & \text { Build. } & 154 & \text { 283-294. }\end{array}$ https://doi.org/10.1016/j.enbuild.2017.08.002.

[14] A. Nutkiewicz, Z. Yang, R.K. Jain, Data-driven Urban Energy Simulation (DUE-S): A framework for integrating engineering simulation and machine learning methods in a multi-scale urban energy modeling workflow, Appl. Energy. $225 \quad$ (2018) 1176-1189. https://doi.org/10.1016/j.apenergy.2018.05.023.

[15] F. Salata, V. Ciancio, J. Dell'Olmo, I. Golasi, O. Palusci, M. Coppi, Effects of local conditions on the multi-variable and multi-objective energy optimization of residential buildings using genetic algorithms, Appl. $\quad$ Energy. 260 (2020). https://doi.org/10.1016/j.apenergy.2019.114289.

[16] P. Shen, W. Braham, Y. Yi, The feasibility and importance of considering climate change impacts in building retrofit analysis, Appl. Energy. 233234 (2019) 254-270. https://doi.org/10.1016/j.apenergy.2018.10.041.
[17] M. Anastasiadou, V. Santos, M. Dias, C. Monteiro, Intelligent Computing Techniques for Energy Performance Classification and Retrofit Scenarios of Buildings: A Systematic Literature Review, (2021) 40.

[18] C. Koo, T. Hong, A dynamic energy performance curve for evaluating the historical trends in the energy performance of existing buildings using a simplified case-based reasoning approach, Energy Build. 92 (2015) 338350. https://doi.org/https://doi.org/10.1016/j.enbuild.2015.02.004.

[19] S. Papadopoulos, B. Bonczak, C.E. Kontokosta, Pattern recognition in building energy performance over time using energy benchmarking data, Appl. $\quad$ Energy. $\quad 221 \quad$ (2018) 576-586. https://doi.org/10.1016/j.apenergy.2018.03.079.

[20] U. Ali, M.H. Shamsi, C. Hoare, E. Mangina, J. O’Donnell, A data-driven approach for multi-scale building archetypes development, ENERGY Build. 202 (2019).

[21] Minister Dello Sviluppo Economico, Decreto interministeriale 26 giugno 2015 - Adeguamento linee guida nazionali per la, Gov. Ital. (n.d.). https://www.mise.gov.it/index.php/it/normativa/decretiinterministeriali/2032968-decreto-interministeriale-26-giugno-2015adeguamento-linee-guida-nazionali-per-la-certificazione-energeticadegli-edifici.

[22] S.C. Etripodi, Studio di Ingegneria, (2021). https://www.studiocardilloetripodi.it/home/energia/attestato-prestazioneenergetica-ape-certificazioni-energetiche-edifici-residenzialicommerciali-industriali.

[23] I.N. of L.E.A. (RENAEL) Ezilda Costanzo, Alessandro Federici, Anna Martino, Marcello Antinucci, Gianmario Varalda, Implementation of the EPBD in Italy, 2016. https://epbd-ca.eu/outcomes/20152018/book2018/countries/italy/.

[24] H. Akoglu, User's guide to correlation coefficients, Turkish J. Emerg. Med. 18 (2018) 91-93. https://doi.org/10.1016/j.tjem.2018.08.001.

[25] F.T. Liu, K.M. Ting, Z.H. Zhou, Isolation forest, Proc. - IEEE Int. Conf. Data Mining, ICDM. (2008) 413-422. https://doi.org/10.1109/ICDM.2008.17.

[26] F.T. Liu, K.M. Ting, Z.H. Zhou, Isolation-based anomaly detection, ACM Trans. Knowl. Discov. Data. 6 (2012) 1-44. https://doi.org/10.1145/2133360.2133363.

[27] N.R. Prasad, S. Almanza-Garcia, T.T. Lu, Anomaly detection, Comput. Mater. Contin. $\quad 14 \quad$ (2009) https://doi.org/10.1145/1541880.1541882.

[28] G.A. Susto, A. Beghi, S. McLoone, Anomaly Detection through on-line Isolation Forest: An application to plasma etching, (2017) 89-94. https://doi.org/10.23919/mipro.2017.7966552.

[29] B. Iglewicz, Summarizing Data with Boxplots, in: Int. Encycl. Stat. Sci., Springer Berlin Heidelberg, 2011: pp. 1572-1575. https://doi.org/10.1007/978-3-642-04898-2_582.

[30] F.I. Mowbray, S.M. Fox-Wasylyshyn, M.M. El-Masri, Univariate Outliers: A Conceptual Overview for the Nurse Researcher, (n.d.). https://doi.org/10.1177/0844562118786647.

[31] G. Eason, B. Noble, and I. N. Sneddon, "On certain integrals of LipschitzHankel type involving products of Bessel functions," Phil. Trans. Roy. Soc. London, vol. A247, pp. 529-551, April 1955.

[32] J. Clerk Maxwell, A Treatise on Electricity and Magnetism, 3rd ed., vol. 2. Oxford: Clarendon, 1892, pp.68-73.

[33] I. S. Jacobs and C. P. Bean, "Fine particles, thin films and exchange anisotropy," in Magnetism, vol. III, G. T. Rado and H. Suhl, Eds. New York: Academic, 1963, pp. 271-350.

[34] K. Elissa, "Title of paper if known," unpublished.

[35] R. Nicole, "Title of paper with only first word capitalized," J. Name Stand. Abbrev., in press.

[36] Y. Yorozu, M. Hirano, K. Oka, and Y. Tagawa, "Electron spectroscopy studies on magneto-optical media and plastic substrate interface," IEEE Transl. J. Magn. Japan, vol. 2, pp. 740-741, August 1987 [Digests 9th Annual Conf. Magnetics Japan, p. 301, 1982].

[37] M. Young, The Technical Writer's Handbook. Mill Valley, CA: University Science, 1989. 